\title{
Analysis on the Application of Games on English Teaching
}

\author{
Fanjiao Mao \\ Changsha Medical University, Changsha, Hunan, 410219
}

Keywords: English teaching; games; application prospect

\begin{abstract}
With the deepening of the new curriculum reform, primary school English teaching must innovate teaching ideas and teaching methods. This is an important topic in the current primary school English teaching and research. This paper starts from the connotation and characteristics of educational games and analyzes the important role of the implementation of educational games in English teaching in primary schools. It focuses on the application of word teaching, the application of listening teaching, the application of grammar teaching, and the application of phonetic teaching. The application of educational games in English teaching in primary schools is analyzed. Finally, it is concluded that educational games have great prospects for the development of English teaching in primary schools. At the same time, in order to play a bigger role, relevant experts, scholars, first-line teachers, and game designers must be required to work together to effectively improve English teaching in primary schools, classroom level and efficiency.
\end{abstract}

\section{Introduction}

Under the trend of world economic integration and cultural diversification of the world, English has become the universal language of all countries in the world. The widespread use of English has also made English education highly valued. Our country has set up English courses from elementary school, but English is still difficult to learn as a foreign student, especially for elementary school students whose physical and mental development is not perfect. Therefore, the application of game teaching method in English teaching can create a relaxing and pleasant learning environment for students through fun games, so that students can not only learn English knowledge but also experience the joy brought by English class and promote the healthy growth of primary school students.

\section{Application of Game Teaching Method in English Teaching}

With the reform and deepening of China's new curriculum standards, the traditional teaching methods and modern teaching gradually appear to be derailed. The application of the most novel teaching model in the primary school English teaching plays a multiple role. First of all, the game teaching method has a certain purpose. When applied in primary school English, the teacher will design the game according to the content of the teaching, aiming at the destination, and apply the game with purpose to the English teaching. Through the fun of the game to achieve the effectiveness of English teaching; Second, the application of game teaching method in primary school English teaching is mainly to give educational significance to the game, so that students can master the knowledge in the process of the game, but also can learn to unite and cooperate. Helping each other, communicating with others and other skills; Finally, the specific educational approach of the game teaching method determines that its application in primary school English teaching can create a happy learning atmosphere for students and enable students to feel through interesting games and interesting scenes. The charm of English learning, thereby improving the efficiency of teachers' English teaching. The characteristics of the primary school English subject itself and the limitations of the teacher's teaching methods lead to students' enthusiasm for learning in the process of English learning is not high, and the learning effect is generally low. The application of game pedagogy can enable students to feel happy and relaxed in a stressful learning environment. At the same time, the use of games in English practice can strengthen students' language expression skills, 
thereby helping students to better apply English to practical situations. Go to life.

\section{Connotation and Functional Characteristics Analysis of Game Teaching Method}

The game pedagogy is mainly applicable to the teaching of children in the age stage of the child. It should be targeted and targeted when it is applied. It is a form of teaching that reflects the surrounding life through imitation and imagination so that the students can Use games to achieve a good presentation of school results. Game teaching is a combination of both game and education. In the application, competition is based on victory (Shen Huanhuan 2015). The application of game pedagogy can effectively cultivate students' knowledge, skills, emotions, attitudes, values, etc., and introduce them into English teaching in primary schools. This will enable students to develop other students' abilities while learning English, so that students can show interest. learning English.

The reason why game pedagogy has been widely used in primary school English teaching is mainly its own significant functional characteristics. From the perspective of its basic characteristics of teaching, it has a more obvious purpose. Each application of the game has its own purpose. For example, the answer to the mystery is that the letter riddles are based on the pronunciation of the letters and the specific meanings they represent. The detailed design, such as "Whatletter is a kind of drink?" Liu Wenjia 2015). The solution to the problem and the discovery of the treasures are the use of games for educational purposes. The educational and recreational features of the game pedagogy are more prominent. In addition, from the competitive and normative aspects of game teaching methods, games will compete in various forms. Through the implementation of games, students' teamwork awareness will be strengthened. Some games have a certain degree of difficulty. Therefore, they are also challenging for students.

\section{Application of Game Teaching Method in English Teaching in Primary School}

The advantages of the game teaching method in primary school English teaching are self-evident. Its application in English teaching can not only improve teachers' teaching results, but also enable students to feel the charm of language in the process of English learning, and experience in the English class. To be happy. Therefore, in the specific application process, teachers are required to conduct careful analysis and research on the teaching content. According to the teaching content and the actual teaching objectives, the game plan can be formulated in a targeted way. In the game design process, it cannot be separated from the teaching content. Give full play to the purpose of educational education. There are many modules in the English subject. For example, English for primary schools, vocabulary teaching, reading teaching, and writing teaching are all important parts of English teaching. For each kind of game, what kind of game should be set up, teachers should think clearly in advance. Only when the game is more targeted can it enhance the students' enthusiasm for learning by deepening the memory and understanding of knowledge while mobilizing the atmosphere in the classroom. For example, when explaining "Do you like pears", teachers can use multimedia to make courseware for students, display various fruits in the courseware, and then display the corresponding words, and then design a "game for finding friends" so that students can share fruits with Corresponding English words are linked together. In this way, students can not only grasp various fruit words quickly, but also can deepen students' impressions in the course of repeated practice, which is much more significant than rote learning.

The application of game teaching method in primary school English teaching should be based on the actual situation of students. This kind of teaching method itself is to carry out classroom teaching from the perspective of students, so teachers should fully understand students' actual needs when applying game teaching methods. According to the students' interests and hobbies, they can improve the fun of the game in the process of designing the game, let the students feel happy in the English class, gradually fall in love with English learning, and improve their English learning. Pupils are naturally curious, but the concentration time of attention during class is limited. Therefore, teachers should make full use of the game teaching method to attract students' attention in the teaching, so that the students are always in a state of excitement in the classroom and can be 
positive. Respond to the content taught by the teacher and change the boring atmosphere of the traditional English class, making English teaching more dynamic. Taking "What time is it" as an example, teachers can design a role-playing game that divides students into different groups, allowing each group member to discuss freely, and then use "What time is it? It's 8O'clock." "It's time to eat breakfast" is the core sentence pattern. The group members play different roles to practice. Through this teaching method, students can not only have a clear understanding of the characters in the role-playing, but also can improve their ability to grasp English knowledge in the process of dialogue practice, and the role-playing game is fun and flexible. Sexuality is strong. Students can freely express their own ideas in the process of performance. They are no longer limited by a single lecture system and are of great significance to the physical and mental health of primary school students.

The application of game teaching method in English teaching can effectively stimulate the atmosphere of the classroom, especially the curiosity of students in primary school English teaching, which makes them more willing to participate in the game. Although the game teaching method has the advantages that traditional teaching methods cannot match, if Excessive gamification in the classroom will make students easily overly addicted to the game, the educational significance of the game can not be effectively played, and classroom teaching results will be adversely affected. The application of game pedagogy in primary school English teaching has changed the teacher-centered teaching model in traditional teaching. Therefore, teachers should position themselves as organizers, guides, participants, and correctors in game teaching. Teachers should The English class is returned to the students, allowing them to perceive knowledge and experience happiness in the process of the game. The teacher then plays the role of guiding and helping. Once the students have ignored the phenomenon of learning in the game, the teacher must carry out timely control and guide the students to return to Learning to come. In addition, teachers in the game design process must also fully consider the harm caused by excessive games, good control of the game scale, making English games can really play the purpose of education and teaching.

For example, in the course of teaching new letters, teachers can use related game settings to allow students to consolidate the knowledge they have learned, and to enable students to easily master the knowledge of letters in the playing of games. Through frog jumping game settings, with the support of multimedia technology, students can control the frogs on the sticks by pressing keys and let them jump in the flowing river. There are a lot of wandering lotus leaves in the river. Each lotus leaf is a letter to learn, and through the system prompts the frog jumps to the corresponding letter lotus leaf. The use of this game has strengthened students' ability to use their eyes and hands, and is also effective in recognizing and remembering letters. The application of game teaching methods can enable students to break through the difficulties and priorities of primary school English teaching one by one. Each class will have difficulties and priorities in English learning. Teachers' repeated reading and teaching alone will not arouse students' interest in learning. However, implementing teaching in a scientific way will break the previous solidified teaching model. For example, for difficult-to-read or confusing letters, words, and sentences, it is possible to implement teaching through a discriminative game such as "spoken words" or "a comparison". For example, in the course of the "speaking" game application, the teacher silently tells the first student in each group to pass it down and repeat it with the last student. In the end, the teacher commented and identified the similar sounds. In the course of the game, students' enthusiasm was mobilized, students' interest in learning English was stimulated, and the efficiency of learning was improved.

\section{Conclusion}

Educational games have great development prospects in the future of primary school English teaching. At the same time, if you want to play a greater role, you must ask related experts, scholars, frontline teachers, and game designers to work together to effectively improve the primary school English teaching classroom. Level and efficiency. 


\section{References}

[1] Younan. Games in the application of primary school English teaching classroom research [J]. Talent, 2014, (30): 54 - 55.

[2] Yao Yali, Ling Xiao. The application of game teaching method in primary school English teaching [J]. Journal of Weifang Engineering Vocational College, 2015, (04): 102 - 105

[3] Wei Ting. Analysis of the motivation of learning games to motivate learning motivation and design strategies [J]. Modern Educational Technology, 2009, (1): 55-58.

[4]. Ru Ruwei, Li Yi. Research on the Definition and Characteristics of Practical Electronic Educational Games [J]. Journal of Distance Education, 2008, (5): 75-78.

[5] Shang JJ, Zhuang S Y. Research on educational application value of games [J]. Journal of Distance Education. 2009, (1): 63-68. 